\title{
Fetal Leptin Influences Birth Weight in Twins with Discordant Growth
}

\author{
SUREN R. SOORANNA, STUART WARD, AND REKHA BAJORIA
}

University of Manchester, Academic Unit of Obstetrics and Gynaecology and Reproductive Health Care, St Mary's Hospital for Women and Children, Manchester M13 OJH, U.K. [S.W., R.B.]; Imperial College

School of Medicine, Department of Maternal \& Fetal Medicine, Hammersmith and Queen Charlotte's Hospital [R.B.]; and Chelsea and Westminster Hospital [S.R.S.], London SW 6, U.K.

\begin{abstract}
The objective of this study was to determine the plasma leptin concentrations in twin pregnancies in relation to chorionicity and discordant fetal growth. We studied 53 twin pregnancies of which 26 had growth discordance of $\geq 20 \%$ and 27 were concordant for growth (discordance of $\leq 10 \%$ ). Paired maternal and fetal blood samples were obtained at birth. Plasma leptin concentrations were measured by RIA. In discordant monochorionic pregnancies, fetal plasma leptin concentrations in the intrauterine growth-restricted twins were lower than the co-twins with normal growth (mean difference, $3 \mathrm{ng} / \mathrm{mL}$; 95\% CI, 2.2 to 3.3 $\mathrm{ng} / \mathrm{mL} ; p<0.001)$, whereas no such differences were present between concordant monochorionic twin pairs (mean difference, $0.1 \mathrm{ng} / \mathrm{mL} ; 95 \% \mathrm{CI},-0.2$ to $0.5 \mathrm{ng} / \mathrm{mL}$; NS). Similarly, fetal plasma leptin concentrations in appropriate-for-gestational-age twins were higher than in the intrauterine growth-restricted twins of the discordant dichorionic pregnancies (mean difference, 2.4 $\mathrm{ng} / \mathrm{mL} ; 95 \% \mathrm{CI}, 1.8$ to $3.1 \mathrm{ng} / \mathrm{mL} ; p<0.001)$. No such differences were present between the concordant dichorionic twin pairs (mean difference, $0.2 \mathrm{ng} / \mathrm{mL} ; 95 \% \mathrm{CI},-0.1$ to $0.5 \mathrm{ng} / \mathrm{mL}$; NS). Maternal plasma leptin concentrations were comparable among all four groups and were higher than the fetal levels. Fetal
\end{abstract}

\section{ABSTRACT}

plasma leptin concentrations of the intrauterine growth-restricted twins of discordant monochorionic and dichorionic pregnancies were comparable. There was a positive association between cord plasma leptin concentrations and the birth weight of twin pairs $(y$ $=0.002 x-0.32 ; r=0.63 ; p<0.001 ; n=106)$. A significant positive association was also found between percent differences in birth weight and fetal delta plasma leptin concentrations of the discordant monochorionic and dichorionic twin pairs $(y=0.057 x$ $+0.93 ; r=0.60 ; p<0.001, n=26)$. In conclusion, irrespective of chorionicity, plasma leptin concentrations in intrauterine growth-restricted twins were 2-fold lower than their co-twins with normal growth. These differences may be attributed to placental factors. (Pediatr Res 49: 667-672, 2001)

MC, monochorionic

Abbreviations:

DC, dichorionic

MZ, monozygotic

DZ, dizygotic

IUGR, intrauterine growth restriction

AGA, appropriate growth for gestational age
Leptin is a $16-\mathrm{kD}$ protein encoded by the $o b$ gene and produced by adipocytes (1). It regulates body weight through a negative feedback signal between the adipose tissue and the hypothalamic centers of satiety, thereby causing a decrease in food intake and increases in body temperature and energy expenditure (2). In obese or normal weight children, as in adults, plasma leptin concentrations closely correlate with body weight and percentage body fat $(3,4)$. Raised plasma leptin concentrations are observed during pregnancy and in fetal life $(5,6)$. Several recent studies have demonstrated a positive correlation between plasma leptin concentrations in cord blood and body weight at birth $(7,8)$. The mechanisms by

Received May 29, 2000; accepted November 30, 2000.

Correspondence and reprint requests: Rekha Bajoria, M.D., St Mary's Hospital, Whitworth Park, Manchester, M13 OJH, U.K.; e-mail: rekha.bajoria@man.ac.uk

Supported by Research and Graduate Support Unit, University of Manchester, U.K. which maternal and fetal or neonatal weight and fat mass are regulated during pregnancy and in fetal life are poorly understood.

Leptin is synthesized by adipocytes and the human placenta $(8,9)$. The adipose tissue in the newborn is capable of synthesizing and secreting hormonal factors, which provide feedback loops between fat tissue and endocrine glands, thereby controlling lipolysis and thermogenesis. As the accumulation of fat mass is dramatically reduced in fetuses with IUGR (10), it is not surprising that many investigators have reported markedly lower plasma leptin concentrations in newborn infants with IUGR than in those with normal growth (11-13). However, from these studies it is not known whether this association is caused by the impact of intrauterine malnutrition per se, which leads to poor accumulation of fat mass, or whether it is a coincidence between the putative variables that may alter plasma leptin concentrations and reduce weight at birth. It is 
also unclear whether differences in gestational age, maternal height, birth order, or sex may have led to this association.

Recent data suggest that there is diurnal variation in the plasma leptin concentrations with an approximately $50 \%$ increase in levels from nadir to peak (14). Furthermore, leptin concentrations are shown to be higher in the spring and summer than in the fall and are higher in infants born before noon (15). Another potentially confounding variable is that of the genetic influence. It has been shown that the presence of a family history of obesity on the paternal side, but not on the maternal side, is associated with elevated cord leptin concentration (15). No previous study has made any attempt to isolate the effects of these potentially confounding variables on plasma leptin concentrations in the fetus with abnormal growth and those with normal growth.

We studied twin pregnancies with growth discordance as a model to evaluate the association between plasma leptin concentrations and fetal growth. This model removed some of the above confounding variables by optimizing for diurnal, maternal, and intrauterine environment. Furthermore, abnormal fetal growth, and, in particular, growth restriction of at least one twin, is associated with a 4- to 6-fold higher incidence of perinatal mortality and morbidity (16). The effected fetuses are susceptible not only to all the risks that the singleton IUGR entails, but in addition to a higher risk of cerebral palsy (16). Although several factors may contribute to growth restriction of one twin, in MC pregnancy this may be predominantly related to placental factors such as unequal sharing of the placental parenchyma or inter-twin transfusion (17-19). In contrast, the causes of growth restriction of one of a DC twin pair might be attributed to poor placentation or fetal genome, with the exclusion of maternal factors. In this study, we made a further attempt to evaluate fetal plasma leptin concentrations in relation to chorionicity to clarify whether placental or fetal factors influence the levels of circulating leptin at birth.

\section{METHODS}

Patients. Fifty-three women with twin pregnancies were studied. Chorionicity was established prenatally and was confirmed at birth. The pregnancy was said to be MC in the presence of concordant genitalia, intrafetal membrane thickness $<2.0 \mathrm{~mm}$, and a single placental mass. The diagnosis of DC was made if there were two placental masses, discordant genitalia, twin peak sign, and intrafetal membrane thickness $>$ $2.0 \mathrm{~mm}(16)$.

The diagnosis of discordant growth was made when the difference in estimated birth weight was $\geq 20 \%$ with absence of polyhydramnios in the larger twin's sac and the smaller twin's abdominal circumference was $\leq 5$ th centile with abnormal umbilical artery Doppler waveforms. This constituted the study group.

The twins who had concordant growth $(\leq 10 \%)$ and normal amniotic fluid volumes in both sacs (amniotic fluid index of $\leq 24 \mathrm{~cm}$ ) throughout the pregnancy constituted the control group.

In the DC twin pregnancies, there were 17 sets of twins with unlike and seven with like sex pairing. In like sex pairs, zygosity information was available by DNA analysis in four cases. However, in the remaining three sets of twins, zygosity was assigned by phenotype assessment by the parents (20).

All pregnancies were monitored by serial ultrasound scans for fetal growth and amniotic fluid volume. We excluded those pregnancies that were complicated by chronic twin-twin transfusion syndrome, intrauterine demise of one twin, fetal structural and chromosomal abnormalities, selective feticide, and embryo reduction. Pregnancies with the maternal complications of hypertension, preeclampsia, diabetes, or renal and cardiac disease were also excluded.

Collection of samples. Matched maternal and umbilical venous blood samples were obtained from twin pairs at delivery. Blood samples were collected into tubes containing EDTA and centrifuged, and the plasma was stored at $-70^{\circ} \mathrm{C}$ until batch assay was performed. Maternal samples were not available from four DC and five MC pregnancies. Samples were collected at the Institute of Obstetrics and Gynaecology, Hammersmith and Queen Charlotte's Hospitals $(n=44)$, and St Mary's Hospital, Manchester $(n=9)$. All women gave informed consent for the collection of maternal blood samples, which was approved by the local hospital ethics committee.

Measurement of plasma leptin concentrations. The plasma concentration of leptin was measured by RIA using commercially available kits obtained from Linco Research (St. Louis, MO, U.S.A.). The intra-assay coefficient of variation for leptin was $<5 \%$.

Data analysis. Clinical data are expressed as medians and ranges, whereas leptin concentrations are expressed as mean with $95 \%$ CI. For parametric data, the paired $t$ test was used to compare values within twin pairs and the $t$ test between groups. Fisher's exact test was used for blocked comparisons. For nonparametric data, comparisons between groups were performed using the Mann-Whitney test. Correlations between plasma fetal leptin concentrations and birth weight were sought using the Spearman coefficient. Percentage growth discordance was calculated as [(birth weight of larger twin minus birth weight of smaller twin) divided by birth weight of larger twin)] times 100 .

\section{RESULTS}

Clinical details of MC and DC/DZ twins are given in Table 1. In this study, as all DC twin pairs were DZ (17 unlike sex pairs, and seven like sex pairs were also DZ by virtue of DNA analysis), we used the abbreviation DC/DZ. Furthermore, in the $\mathrm{DC} / \mathrm{DZ}$ group, as fetal plasma leptin concentrations were comparable between like and unlike sex twin pairs, data are grouped together according to percent differences in birth weight.

\section{Leptin concentration}

MC twins. The maternal plasma leptin concentrations were comparable between concordant and discordant MC pregnancies $(30.4 \pm 5 \mathrm{ng} / \mathrm{mL}$ versus $21.5 \pm 3 \mathrm{ng} / \mathrm{mL}$; NS).

In the discordant growth group, plasma leptin concentrations in the IUGR twins were lower than in the AGA twins (mean difference, $2.7 \mathrm{ng} / \mathrm{mL}$; 95\% CI, 2.2 to $3.3 \mathrm{ng} / \mathrm{mL} ; p<0.001$ ) 
Table 1. Clinical variables for MC and DC twins with or without discordant growth

\begin{tabular}{|c|c|c|c|c|c|c|}
\hline \multirow[b]{2}{*}{ Variable } & \multicolumn{3}{|c|}{ Monochorionic twins } & \multicolumn{3}{|c|}{ Dichorionic twins } \\
\hline & $\begin{array}{l}\text { Concordant } \\
(n=15)\end{array}$ & $\begin{array}{l}\text { Discordant } \\
(n=14)\end{array}$ & $p$ value & $\begin{array}{c}\text { Concordant } \\
(n=12)\end{array}$ & $\begin{array}{l}\text { Discordant } \\
(n=12)\end{array}$ & $p$ value \\
\hline \multicolumn{7}{|l|}{ Birth weight $(\mathrm{g})$} \\
\hline Twin $1 / \mathrm{AGA}$ & $2534(1580-3040)$ & $1770(1240-3140)$ & NS & $2175(1130-3252)$ & $2240(1600-2888)$ & NS \\
\hline Twin 2/IUGR & $2410(1465-2920)$ & $1170(650-2440)$ & $<0.01$ & $2050(1000-2964)$ & $1490(1000-2308)$ & $<0.001$ \\
\hline$\%$ Discordance in weight & $4(0.4-9)$ & $26(20-58)$ & $<0.001$ & $4(0.3-10)$ & $27(21-47)$ & $<0.001$ \\
\hline Unlike sex & None & None & & $8 / 12$ & $9 / 12$ & NS \\
\hline \multicolumn{7}{|l|}{ Like sex } \\
\hline Male/Male & $5 / 15$ & $4 / 14$ & NS & $2 / 12$ & $3 / 12$ & \\
\hline Female/Female & $10 / 15$ & $10 / 14$ & NS & $2 / 12$ & None & \\
\hline \multirow[t]{2}{*}{ Umbilical artery Doppler IUGR twin $\dagger$} & & AEDF-7 & & & AEDF-5 & \\
\hline & & Raised PI 6 & & & Raised PI 5 & \\
\hline Delta arterial $\mathrm{pH}$ & $0.06(0.02-0.1)$ & $0.18(0.12-0.24)$ & $<0.01$ & $0.06(0.01-0.11)$ & $0.15(0.1-0.2)$ & $<0.05$ \\
\hline Delta arterial $\mathrm{PO}_{2}(\mathrm{~mm} \mathrm{Hg})$ & $2.5(0.2-4.6)$ & $12(9-15)$ & $<0.05$ & $2.5(1.4-3.7)$ & $19(16-22.0)$ & $<0.001$ \\
\hline
\end{tabular}

Values reported are median (range). CS, cesarean section; AEDFP, absent end-diastolic flow; PI, pulsatility index.

$\dagger$ Umbilical artery Doppler waveform of twin 1 and twin 2 of concordant growth group and AGA twin of discordant growth group were normal. * $p$ value by Fisher's exact test.

and also twin 1 (mean, $4.0 \mathrm{ng} / \mathrm{mL} ; 95 \% \mathrm{CI}, 3.0$ to $4.9 \mathrm{ng} / \mathrm{mL}$; $p<0.001$ ) and twin 2 (mean, $3.9 \mathrm{ng} / \mathrm{mL} ; 95 \% \mathrm{CI}, 3.0$ to 4.7 $\mathrm{ng} / \mathrm{mL} ; p<0.001$ ) of the concordant growth groups (Fig. 1). There were no significant differences in the leptin concentrations between twin pairs with concordant growth (mean difference, $0.12 \mathrm{ng} / \mathrm{mL} ; 95 \% \mathrm{CI},-0.2$ to $0.5 \mathrm{ng} / \mathrm{mL}$; NS; Fig. 2 ) and AGA twins of the discordant group $(p=0.18)$. The delta plasma leptin concentrations in the discordant growth group were higher than in the twins in the concordant group (mean difference, $2.7 \mathrm{ng} / \mathrm{mL} ; 95 \% \mathrm{CI}, 2.2$ to $3.2 \mathrm{ng} / \mathrm{mL}$ versus 0.1 $\mathrm{ng} / \mathrm{mL} ; 95 \%$ CI, -0.2 to $0.5 \mathrm{ng} / \mathrm{mL}$ ).

In discordant MC pregnancies, there were five pairs of male and 10 pairs of female twins, and in the concordant group, there were 10 pairs of female and five pairs of male twins. The interpair fetal plasma leptin concentrations in female twins of concordant (mean difference, $0.3 \mathrm{ng} / \mathrm{mL} ; 95 \% \mathrm{CI},-0.1$ to 0.8 $\mathrm{ng} / \mathrm{mL}$ versus $0.3 \mathrm{ng} / \mathrm{mL} ; 95 \% \mathrm{CI},-0.2$ to $0.7 \mathrm{ng} / \mathrm{mL} ; \mathrm{NS}$ ) and
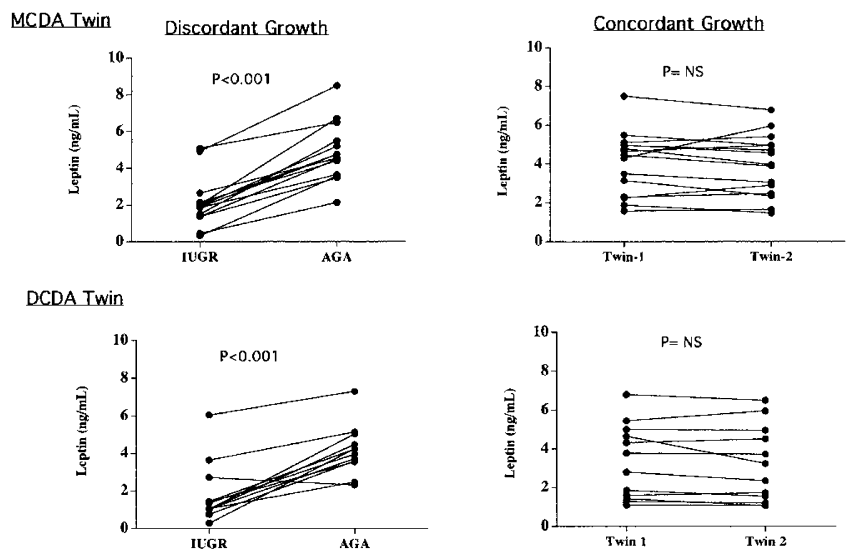

Fig. 1. Fetal plasma leptin concentrations in MC and DC twins with or without growth discordance. discordant growth group (mean difference, $3 \mathrm{ng} / \mathrm{mL}$; 95\% CI, 2.3 to $3.3 \mathrm{ng} / \mathrm{mL}$ versus $2.7 \mathrm{ng} / \mathrm{mL} ; 95 \% \mathrm{CI}, 1.5$ to $3.8 \mathrm{ng} / \mathrm{mL}$; NS) were comparable with those of the male sex twins.

DC twins. The maternal plasma leptin concentrations were comparable between discordant and concordant growth twin pairs $(21.0 \mathrm{ng} / \mathrm{mL} ; 95 \% \mathrm{CI}, 10.1$ to $31.3 \mathrm{ng} / \mathrm{mL}$ versus 25.0 $\mathrm{ng} / \mathrm{mL} ; 95 \% \mathrm{CI}, 13.2$ to $36.7 \mathrm{ng} / \mathrm{mL}$; NS).

In the discordant growth group, fetal plasma leptin concentrations in the IUGR twin were lower than in AGA twins (mean difference, $2.4 \mathrm{ng} / \mathrm{mL} ; 95 \% \mathrm{CI}, 1.8$ to $3.1 \mathrm{ng} / \mathrm{mL} ; p<0.001)$ and the twin $1(p<0.001)$ and twin $2(p<0.001)$ of the control group (Fig. 2). There were no significant differences in the leptin concentrations between concordant twin pairs (mean difference, $0.2 \mathrm{ng} / \mathrm{mL} ; 95 \% \mathrm{CI},-0.1$ to $0.5 \mathrm{ng} / \mathrm{mL} ; p=0.50$; Table 2), which were similar to those of the AGA fetus of the discordant growth group $(p=0.11)$. The delta plasma leptin concentrations in the discordant group were higher than in the control group (mean difference, $2.4 \mathrm{ng} / \mathrm{mL} ; 95 \% \mathrm{CI}, 1.8$ to 3.1 $\mathrm{ng} / \mathrm{mL}$ versus $0.2 \mathrm{ng} / \mathrm{mL} ; 95 \% \mathrm{CI},-0.1$ to $0.5 \mathrm{ng} / \mathrm{mL} ; p<$ $0.001)$.
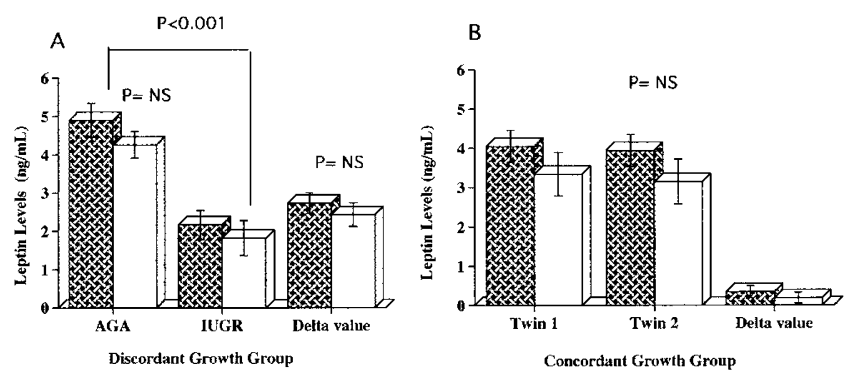

Fig. 2. Comparison of plasm leptin concentrations of MC (hatched bars) and DC (open bars) twin pairs with $(A)$ and without $(B)$ discordant growth. 
Table 2. Plasma leptin values for MC and DC twins with or without discordant growth

\begin{tabular}{|c|c|c|c|c|}
\hline \multirow[b]{2}{*}{ Variable } & \multicolumn{2}{|c|}{ Concordant growth } & \multicolumn{2}{|c|}{ Discordant growth } \\
\hline & $\begin{array}{l}\text { Monochorionic } \\
\quad(n=14)\end{array}$ & $\begin{array}{l}\text { Dichorionic } \\
(n=12)\end{array}$ & $\begin{array}{l}\text { Monochorionic } \\
\quad(n=15)\end{array}$ & $\begin{array}{c}\text { Dichorionic } \\
(n=12)\end{array}$ \\
\hline Twin 2/IUGR (ng/mL) & $3.9 \pm 1.6$ & $3.2 \pm 2.0$ & $2.2 \pm 1.4$ & $1.8 \pm 1.6$ \\
\hline Delta values $(\mathrm{ng} / \mathrm{mL})$ & $0.12 \pm 0.7$ & $0.2 \pm 0.5$ & $2.7 \pm 1.0$ & $2.4 \pm 1.1$ \\
\hline Maternal (ng/mL) & $30.4 \pm 18.5$ & $21 \pm 19.0$ & $21.5 \pm 11.2$ & $24.9 \pm 20.7$ \\
\hline
\end{tabular}

All values are expressed as mean \pm SEM. There were no significant differences between sets of MC and DC twins.

In discordant DC pregnancies, there were seven female and five male IUGR twins and six each of male and female AGA twins. In contrast, there were nine female and 15 male twins in the concordant group. In the discordant group, fetal plasma leptin concentrations between female and male IUGR (mean, $1.6 \mathrm{ng} / \mathrm{mL} ; 95 \% \mathrm{CI}, 0.2$ to $2.9 \mathrm{ng} / \mathrm{mL}$ versus $2.3 \mathrm{ng} / \mathrm{mL} ; 95 \%$ CI, 1.4 to $3.3 \mathrm{ng} / \mathrm{mL}$; NS) and AGA twins (mean, $3.8 \mathrm{ng} / \mathrm{mL}$; 95\% CI, 3.1 to $4.4 \mathrm{ng} / \mathrm{mL}$ versus $4.8 \mathrm{ng} / \mathrm{mL}$; $95 \%$ CI, 3.6 to 5.9 $\mathrm{ng} / \mathrm{mL}$; NS) were comparable.

In the concordant growth group, the fetal plasma leptin concentrations were comparable between female and male infants (mean, $0.3 \mathrm{ng} / \mathrm{mL} ; 95 \% \mathrm{CI},-0.1$ to $0.8 \mathrm{ng} / \mathrm{mL}$ versus $0.3 \mathrm{ng} / \mathrm{mL} ; 95 \% \mathrm{CI},-0.2$ to $0.7 \mathrm{ng} / \mathrm{mL}$; NS).

\section{Comparison between $\mathrm{MC}$ and $\mathrm{DC}$ twin groups}

In the discordant growth group, the delta fetal plasma leptin concentrations were similar between MC and DC twins (mean difference, $2.7 \mathrm{ng} / \mathrm{mL}$; 95\% CI, 2.2 to $3.3 \mathrm{ng} / \mathrm{mL}$ versus 2.4 $\mathrm{ng} / \mathrm{mL} ; 95 \% \mathrm{CI}, 1.8$ to $3.1 \mathrm{ng} / \mathrm{mL}$; NS),. Similarly, in the concordant group, the delta fetal plasma leptin concentrations were similar between $\mathrm{MC}$ and $\mathrm{DC}$ twin pairs (mean difference, $0.1 \mathrm{ng} / \mathrm{mL} ; 95 \% \mathrm{CI},-0.2$ to $0.5 \mathrm{ng} / \mathrm{mL}$ versus $0.2 \mathrm{ng} / \mathrm{mL} ; 95 \%$ $\mathrm{CI},-0.1$ to $0.5 \mathrm{ng} / \mathrm{mL}$; NS; Fig. 2).

\section{Correlation between fetal plasma leptin concentrations and birth weight}

Irrespective of chorionicity or zygosity, there was a significant positive correlation between the birth weight of all twins and fetal plasma leptin concentrations $(y=0.002 x-0.32 ; r=$ $\left.0.63 ; R^{2}=0.39 ; p<0.001 ; n=106\right)$. Similarly, a positive association was present between percent discordance in birth weight and delta plasma leptin concentrations in twins with discordant growth $\left(y=0.06 x+0.93 ; r=0.60 ; R^{2}=0.36 ; p\right.$ $<0.001, n=26$; Fig. 3). There were no associations between
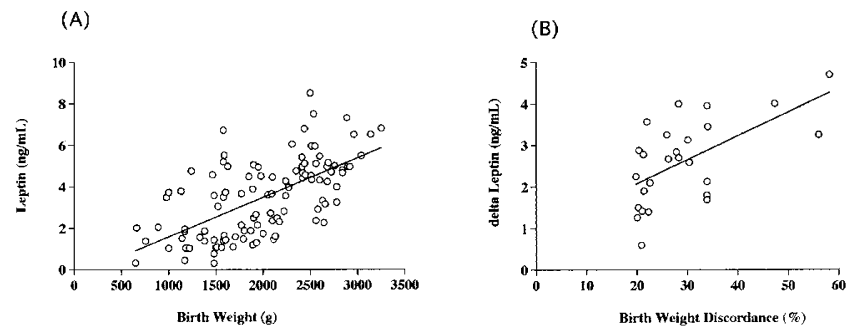

Fig. 3. $A$, correlation between fetal plasma leptin concentrations and birth weight of all twins. $B$, relationship between delta leptin concentrations and percentage differences in birth weight of discordant $\mathrm{MC}$ and DC twins. fetal plasma leptin concentrations, gestational age, and maternal plasma leptin concentrations.

\section{DISCUSSION}

This study reports for the first time that fetal plasma leptin concentrations differ between discordant twin pairs, whereas no such differences were noted between concordant twin pairs. In discordant twins, the plasma leptin concentrations were 2-fold higher in the larger twin than in the growth-restricted co-twin. This occurs irrespective of placental chorionicity or zygosity, which is therefore suggestive of placental dysfunction rather than fetal genetic factors as the prime cause for variations in plasma leptin concentrations between twin pairs. Our findings are consistent with recent reports of 2- to 3-fold decreases in plasma leptin concentrations in singleton fetuses with growth restriction (21). However, our data are in direct conflict with those of Shekhawat et al. (22), who showed no difference in the fetal plasma leptin concentrations between 16 twin pairs. Their data, nevertheless, were not evaluated in relation to chorionicity or growth discordance.

Our data fail to confirm previous observations that fetal plasma leptin concentrations are higher in females than males $(8,12,23)$, Although sexual dimorphism is well established in children and adults, this observation is not confirmed by others at birth $(11,21,24,25)$. This discrepant finding is difficult to explain. It is possible, however, that it may be an effect of sample size studied. Alternatively, absence of sex differences may be related to comparable serum concentrations of estrogens and testosterone or s.c. adipocytes between male and female fetuses at birth.

In the literature the effect of maternal plasma leptin concentrations on fetal growth remains conjectural (26). It has been proposed that a positive correlation between cord and maternal blood leptin concentrations suggests that maternal plasma leptin concentrations may regulate fetal growth by modulating the placental transfer of nutrients and, thereby, fat mass and circulating insulin levels. In the twin model, interpair differences in leptin are unlikely to be attributed to maternal plasma leptin concentrations as the influence of maternal leptin would have been similar in twin pairs.

An important observation of this study is that interpair differences in fetal plasma leptin concentrations in discordant $\mathrm{MC}$ and $\mathrm{DC} / \mathrm{DZ}$ twin pairs were similar, and thereby, it refutes the conventional belief that IUGR in MC twins occurs because of transfer of blood and nutrients along the placental vascular anastomoses (27). Recent studies suggest that the arrangement of the shunts in the placenta is such that intertwin transfusion 
of blood is not a normal event in pregnancies complicated with discordant growth, and fetal growth restriction appears to be independent of type and number of vascular shunts (17-19). This is not all together surprising as plasma leptin concentrations of the larger twins were similar to the twins with concordant growth and, thereby, suggests that growth restriction in twin pregnancies may be related to placental factors.

The placenta is considered to be an important source of leptin in the fetal circulation (11) because 1 ) at birth umbilical venous levels of leptin are higher than arterial levels $(24,28)$; 2) there is a precipitous decline in fetal leptin after birth; and 3) specific leptin mRNA transcripts have been shown to be present in placental tissue in the first and third trimesters $(8,9)$. Furthermore, numerous studies in singletons have shown that plasma leptin concentrations at birth correlate with placental and fetal weight $(13,24,25)$. In this study, no attempt was made to correlate fetal plasma leptin concentrations with the placental weight, because in $\mathrm{MC}$ twins accurate determination of the placental mass belonging to each twins is not feasible (27). Therefore, the cause for differing plasma leptin concentrations in the discordant group remains conjectural. We speculate that it could be caused by differences in secretion of leptin from each twin's portion of the placenta as recent evidence suggest that IUGR twins have abnormal placentas in terms of size $(17,19)$, microvasculature (29), and invasion of spiral arteries by the extravillous trophoblast (30). However, further studies are required to establish an association between placental leptin production and fetal growth.

The functional significance for the 2-fold lower plasma leptin concentrations in the smaller twins is not known. We also found a correlation between fetal plasma leptin concentrations and birth weight. This concurs with the findings from several singleton studies, which report that plasma leptin concentrations at term are directly related to birth weight. A strong association between these two variables has also been reported in diabetic and IUGR infants, with a weak association for AGA fetuses $(7,31-33)$. Furthermore, the strong positive association between the percentage discordance in birth weight and the delta fetal plasma leptin concentrations suggests that intertwin differences in the growth discordant group may be partly related to disparity in fat mass accumulation or intrauterine fetal growth, and points toward a role for leptin as a regulator of fetal growth (33). There is evidence that decrease in body fat is associated with a decline in peripheral leptin concentrations. It is possible that this association may be caused by common factors that regulate both fetal leptin and body fat. It is proposed that this link may be insulin, as leptin might regulate insulin concentration, which then in turn can regulate both fetal growth and leptin production $(34,35)$.

We appreciate that the demonstration of a relationship between fetal plasma leptin concentrations and birth weight in twin pairs does not indicate whether factors that influence fetal growth also regulate leptin synthesis and secretion. Notwithstanding this, the overall variance in the data indicates that $\geq 39 \%$ of the interpair differences in birth weight in the discordant growth group could be accountable by fetal leptin concentrations, whereas the remaining $60 \%$ could be caused by other factors. This is not all together surprising, as the regula- tion of fetal growth in utero is complex, and maternal, placental, and parental genetic variables all may be implicated. Twin studies, by optimizing for the maternal and genetic factors (in MC twins), provide an opportunity to study the role of placental function and fetal hormonal milieu on fetal growth. Recent evidence suggests that fetal growth in utero is regulated by GH or IGFs $(36,37)$. Thus, it is possible that fetal leptin concentration influences intrauterine growth directly as well as through an association with other hormonal systems. This is consistent with evidence from rodents that reduced plasma leptin concentrations and GH levels are normalized by exogenous administration of leptin $(38,39)$. Moreover, leptin is directly associated with circulating concentrations of IGF-I and IGF-1/IGF binding protein-3 ratios (40). We have also recently shown that in MC twins, IUGR twins had higher IGF binding protein-1 and reduced IGF-II levels than did the AGA co-twins (41). Additional factors, such as impaired placental transfermediated fetal undernutrition, may be responsible for the association between fetal growth and leptin. To this end, our recent work also suggests that fetal plasma concentrations of certain essential amino acids in growth-restricted MC twins are markedly reduced (42).

In conclusion, our data suggests that in twins with discordant growth, differences in leptin may be attributed to placental factors rather than maternal or paternal genetic variables. The relationship between leptin and birth weight of twins may be of interest in light of epidemiologic evidence linking birth weight with the development in adulthood of hypertension, obesity, and cardiovascular disease.

\section{REFERENCES}

1. Mantzoros CS, Moschos SJ 1998 Leptin: in search of role(s) in human physiology and pathophysiology. Clin Endocrinol (Oxf) 49:551-567

2. Marti A, Berraondo B, Martinez JA 1999 Leptin: physiological actions. J Physio Biochem 55:43-49

3. Hassink SG, Sheslow DV, de Lancey E, Opentanova I, Considine RV, Caro JF 1996 Serum leptin in children with obesity: relationship to gender and development. Pediatrics 98:201-203

4. Caprio S, Tamborlane WV, Silver D, Robinson C, Leibel R, McCarthy S, Grozman A, Belous A, Maggs D, Sherwin RS 1996 Hyperleptinemia: an early sign of juvenile obesity. Relations to body fat depots and insulin concentrations. Am J Physiol 271:E626-E630

5. Sattar N, Greer IA, Pirwani I, Gibson J, Wallace AM 1998 Plasma leptin concentrations in pregnancy: marker for fat accumulation and mobilization? Acta Obstet Gynecol Scand 77:278-283

6. Sivan E, Lin WM, Homko CJ, Reece EA, Boden G 1997 Leptin is present in human cord blood. Diabetes 46:917-919

7. Gomez L, Carrascosa A, Yeste D, Potau N, Rique S, Ruiz-Cuevas P, Almar J 1999 Leptin values in placental cord blood of human newborns with normal intrauterine growth after 30-42 weeks of gestation. Horm Res 51:10-14

8. Hassink SG, de Lancey E, Sheslow DV, Smith-Kirwin SM, O'Connor DM, Considine RV, Opentanova I, Dostal K, Spear ML, Leef K, Ash M, Spitzer AR, Funanage VL 1997 Placental leptin: an important new growth factor in intrauterine and neonatal development? Pediatrics 100:E1-E6

9. Masuzaki H, Ogawa Y, Sagawa N, Hosoda K, Matsumoto T, Mise H, Nishimura H, Yoshimasa Y, Tanaka I, Mori T, Nakao K 1997 Nonadipose tissue production of leptin: leptin as a novel placenta-derived hormone in humans. Nat Med 3:1029-1033

10. Geary M, Herschkovitz R, Pringle PJ, Rodeck CH, Hindmarsh PC 1999 Ontogeny of serum leptin concentrations in the human. Clin Endocrinol (Oxf) 51:189-192

11. Ertl T, Funke S, Sarkany I, Szabo I, Rascher W, Blum WF, Sulyok E 1999 Postnatal changes of plasma leptin concentrations in full-term and preterm neonates: their relation to intrauterine growth, gender and testosterone. Biol Neonate 75:167-176

12. Jaquet D, Leger J, Levy-Marchal C, Oury JF, Czernichow P 1998 Ontogeny of leptin in human fetuses and newborns: effect of intrauterine growth retardation on serum leptin concentrations. J Clin Endocrinol Metab 83:1243-1246

13. Tamura T, Goldenberg RL, Johnston KE, Cliver SP 1998 Serum leptin concentrations during pregnancy and their relationship to fetal growth. Obstet Gynecol 91:389-395

14. Laughlin GA, Yen SS 1997 Hypoleptinemia in women athletes: absence of a diurnal rhythm with amenorrhea. J Clin Endocrinol Metab 82:318-321 
15. Tarquini B, Tarquini R, Perfetto F, Cornelissen G, Halberg F 1999 Genetic and environmental influences on human cord blood leptin concentration. Pediatrics 103:998-1006

16. Bajoria R, Kingdom JCP 1997 A case for routine determination of chorionicity in multiple pregnancies. Prenat Diagn 17:1207-1225

17. Bajoria R 1998 Vascular anatomy of monochorionic placenta in relation to discordant growth and amniotic fluid volume. Hum Reprod 13:2933-2940

18. Machin G, Still K, Lalani T 1996 Correlations of placental vascular anatomy and clinical outcomes in 69 monochorionic twin pregnancies. Am J Med Genet 61:229236

19. Bajoria R; Wigglesworth J; Fisk N 1995 Angioarchitecture of monochorionic placentas in relation to the twin twin transfusion syndrome. Am J Obstet Gynecol $172: 856-863$

20. Bonnelykke B, Hauge M, Holm N, Kristoffersen K, Gurtler H 1989 Evaluation of zygosity diagnosis in twin pairs below age seven by means of a mailed questionnaire. Acta Genet Med Gemellol (Roma) 38:305-313

21. Koistinen HA, Koivisto VA, Andersson S, Karonen SL, Kontula K, Oksanen L, Teramo KA 1997 Leptin concentration in cord blood correlates with intrauterine growth. J Clin Endocrinol Metab 82:3328-3330

22. Shekhawat PS, Garland JS, Shivpuri C, Mick GJ, Sasidharan P, Pelz CJ, McCormick KL 1998 Neonatal cord blood leptin: its relationship to birth weight, body mass index, maternal diabetes, and steroids. Pediatr Res 43:338-343

23. Matsuda J, Yokota I, Iida M, Murakami T, Naito E, Ito M, Shima K, Kuroda Y 1997 Serum leptin concentration in cord blood: relationship to birth weight and gender. J Clin Endocrinol Metab 82:1642-1644

24. Schubring C, Kiess W, Englaro P, Rascher W, Dotsch J, Hanitsch S, Attanasio A, Blum WF 1997 Levels of leptin in maternal serum, amniotic fluid, and arterial and venous cord blood: relation to neonatal and placental weight. J Clin Endocrinol Metab $82: 1480-1483$

25. Harigaya A, Nagashima K, Nako Y, Morikawa A 1997 Relationship between concentration of serum leptin and fetal growth. J Clin Endocrinol Metab 82:32813284

26. Geary M, Pringle PJ, Persaud M, Wilshin J, Hindmarsh PC, Rodeck CH, Brook CG 1999 Leptin concentrations in maternal serum and cord blood: relationship to maternal anthropometry and fetal growth. Br J Obstet Gynaecol 106:1054-1060

27. Benirschke K, Kaufmann P 1995 Multiple pregnancy. In: Benirschke K, Kaufmann P (eds) Pathology of the Human Placenta, 3rd Ed. Springer-Verlag, New York, pp $636-753$

28. Yura S, Sagawa N, Mise H, Mori T, Masuzaki H, Ogawa Y, Nakao K 1998 A positive umbilical venous-arterial difference of leptin level and its rapid decline after birth. Am J Obstet Gynecol 178:926-930
29. Bruner JP, Anderson TL, Rosemond RL 1998 Placental pathophysiology of the twin oligohydramnios-polyhydramnios sequence and the twin-twin transfusion syndrome. Placenta 19:81-86

30. Matijevic R, Bajoria R 2000 Non-invasive method of evaluation of trophoblast invasion of spiral arteries in monochorionic placenta with twin-twin transfusion syndrome. J Soc Gynecol Invest 7:74A[abstr]

31. Maffei M, Volpe L, Di Cianni G, Bertacca A, Ferdeghini M, Murru S, Teti G, Casadidio I, Cecchetti P, Navalesi R, Benzi L 1998 Plasma leptin concentrations in newborns from normal and diabetic mothers. Horm Metab Res 30:575-580

32. Ong KK, Ahmed ML, Sherriff A, Woods KA, Watts A, Golding J, Dunger DB 1999 Cord blood leptin is associated with size at birth and predicts infancy weight gain in humans. ALSPAC Study Team Avon Longitudinal Study of Pregnancy and Childhood. J Clin Endocrinol Metab 84:1145-1148

33. Clapp 3rd JF, Kiess W 1998 Cord blood leptin reflects fetal fat mass. J Soc Gynecol Invest 5:300-303

34. Rother KI, Accili D 2000 Role of insulin receptors and IGF receptors in growth and development. Pediatr Nephrol 14:558-561

35. Gao Y, Yang Q, Zhou J, Chen L 2000 Association between leptin, insulin, and body fat distribution in 2-diabetes mellitus. Ann N Y Acad Sci 904:542-545

36. Alsat E, Guibourdenche J, Couturier A, Evain-Brion D 1998 Physiological role of human placental growth hormone. Mol Cell Endocrinol 140:121-127

37. McIntyre HD, Serek R, Crane DI, Veveris-Lowe T, Parry A, Johnson S, Leung KC, Ho KK, Bougoussa M, Hennen G, Igout A, Chan FY, Cowley D, Cotterill A, Barnard R 2000 Placental growth hormone (GH), GH-binding protein, and insulin-like growth factor axis in normal, growth-retarded, and diabetic pregnancies: correlations with fetal growth. J Clin Endocrinol Metab 85:1143-1150

38. Carro E, Senaris R, Considine RV, Casanueva FF, Dieguez C 1997 Regulation of in vivo growth hormone secretion by leptin. Endocrinology 138:2203-2206

39. Tritos NA, Mantzoros CS 1997 Leptin: its role in obesity and beyond. Diabetologia 40:1371-1379

40. Paolisso G, Ammendola S, Del Buono A, Gambardella A, Riondino M, Tagliamonte MR, Rizzo MR, Carella C, Varricchio M 1997 Serum levels of insulin-like growth factor-I (IGF-I) and IGF-binding protein-3 in healthy centenarians: relationship with plasma leptin and lipid concentrations, insulin action, and cognitive function. J Clin Endocrinol Metab 82:2204-2209

41. Westwood M, Gibson JM, Sooranna SR, Ward BS, Neilson JP Bajoria R 2001 Gene or placenta as modulator of fetal growth: evidence from IGF axis in twins with discordant growth. Mol Hum Reprod (in press)

42. Bajoria R, Hancock M, Ward S, D'Souza SW, Sooranna SR 2000 Discordant amino acid profiles in monochorionic twins with twin-twin transfusion syndrome. Pediatr Res 48:821-828 